cal shield large, exposed, dark brown and nearly naked. Color grayish like dead leaves, a narrow, dark brown dorsal line. Warts low, flat, but large in three rows. Hairs rather pale, but in general concolorous, stiff, sharp-pointed with clear basal bulbs. Under a high power the spinules are seen to form equidistant rings making the hair appear segmented. Skin densely minutely spinulose. The large pale warts give the appearance of broad, faintly paler subdorsal and lateral bands, separated by the straight dorsal and broken lateral brown lines which gradually become defined.

Stage $I V$. Head light brown, eye black; width $.8 \mathrm{~mm}$., retracted under the large, dark brown cervical shield. Body as before, the large flat warts pale, the ground color only showing as narrow chocolate brown dorsal and subdorsal lines, pale between the segments. Shaft of hairs segmented, the tips black, the bulb at the extreme base, small.

Stage $V$. Width of head I.I mm., as before. Warts brown in large pale gray areas which cut up the dark brown ground into straight dorsal, wavy subdorsal and broken stigmatal bands; subventral region pale brown; incisures dark, obscurely connecting the bands. Joint 2 pale in front, dark behind covering the head. Feet pale. On thorax warts $\mathrm{i}, \mathrm{ii}, \mathrm{iii}, \mathrm{iv}+\mathrm{v}$ and $\mathrm{vi}$ are present, on abdomen $\mathrm{i}+\mathrm{ii}, \mathrm{iii}, \mathrm{iv}+\mathrm{v}$, vi and leg-plate. Hairs segmented, sub-barbuled with basal bulb which shrinks to an annulus at the end of the stage. The whole color becomes dark purplish at this time.

Stage VI. Head pale brown, lighter in the sutures; width $1.6 \mathrm{~mm}$. It is retracted in the hood of joint 2, which is large with a large, dark brown, bisected cervical shield. Body thick and robust, not tapering, densely short hairy. Hairs segmented, with basal bulbs as before, well developed. Color dark velvety brown, reduced to a series of longitudinal and transverse lines by the large, rounded and slightly oblique pale gray areas which surround the upper three warts $(\mathrm{i}, \mathrm{ii}+$ iii, iv + v on thorax, i+ii, iii, iv + v on abdomen). The warts themselves are brown, forming dark centers to the pale patches, not so dark as the ground color. Hairs on lower side of third wart (iv $+v$ ) longer, concealing the subventral region. Feet pale. Spiracles brown, the one on joint 5 moved up. A circular, pale, eversible area surrounds the spiracle on joints 6 and $\mathrm{I}$.

Cocoon. This is irregular, like Harrisina but larger, the main web brownish, a little wrinkly and opaque with some white floss silk outside. Size $13 \times 6 \mathrm{~mm}$. Spun between leaves on the ground.

\title{
DESCRIPTIONS OF TWO NEW FOSSORIAL WASPS.
}

BY William H. ASHMEAd, WAShington, D. C.

The two new fossorial wasps described below were discovered by Prof. George W. Peckham in Wisconsin, who will shortly describe their habits and life histories.

(I) Astata leuthstromi, n. sp. \&.-Length $8 \mathrm{~mm}$. Entirely black, shining, and sparsely clothed with a whitish pubescence. Head rather closely punctate, the clypeus truncate anteriorly and fringed medially with some black hairs, on either side of which are long glittering white hairs; palpi rufo-piceous; first joint of flagellum about $\frac{1}{4}$ longer than the second, joints 2-4 subequal, about four times as long as thick. Mesonotum anteriorly finely punctate, posteriorly for at least half its length as well as the scutellum highly polished and with only a few minute scattered punctures; mesopleura punctate, closer and more distinctly so posteriorly; metathorax with a smooth impunctate space at base, confluently or regularly punctate posteriorly. Wings towards base hyaline, the apical half subfuliginous; the marginal cell is about as long as the first submarginal 
cell; the transverse cubital veins are usually subangulately broken with more or less of a distinct stump of a vein issuing from the angle (the right wing has the third submarginal cell nearly divided into two cells by a spurious cross-vein from the angulation in the second transverse cubitus). Abdomen apparently smooth, impunctate, but with a strong lens the surface exhibits a fine or microscopical reticulation from very fine lines.

Hab. - Haitland, Wis.

Type, No. 3716, U. S. N. M.

This species is allied to $A$. occidentalis $\mathrm{Cr}$. but is readily distinguished by its smaller size, the color of the wings, by the venation and by the smoothness of the mesonotum. Its resemblance to $A$. unicolor Say. is only superficial.

The species has been named in honor of Dr. Leuthstrom, father-in-law of Prof. Peckham, in whose garden the species was found.

(2) Plenoculus peckhami n. sp. $\delta$. Length 3 to $3.5 \mathrm{~mm}$. Black, closely punctate and clothed with a sparse whitish pubescence, the face from middle of eyes and the clypeus with a dense silvery pubescence. Clypeus with a median ridge and produced into a small conic median tooth at apex. Mandibles black, the basal two-thirds closely opaquely punctate, the apical half smooth, shining. Palpi brown-black. Antennae 13- jointed, the flagellum gradually incrassated towards tip ; the first joint of the flagellum is scarcely as long as the second, the third and fourth a little longer than the second and stouter, the joints beyond to the $13^{\text {th }}$ gradually shortening, joints 7-10 being transverse; the terminal joint is large, conic-ovate, as long as the three preceding united. Metathorax rugulose with two short median carinae in a slight depression just before the posterior face. Wings hyaline, faintly dusky at apical margins, the tegulae, stigma and veins brownblack, the marginal cell is sublanceolate with the extreme apex truncate and with an appendage; the second submarginal cell is triangular, petiolate, the second recurrent nervure entering it a little beyond the middle. Hind tibial spurs and the three basal joints of tarsi, whitish. Abdomen long, ovate, a little longer than the head and thorax united, subopaque, finely punctate, sericeous, except lateral triangular spaces, separated by a grooved line, on second, third and fourth dorsal segments, which are smooth and shining

Hab.- Haitland, Wisconsin.

Type, No. 3717, U. S. N. M.

Quite distinct from all other species described in this genus by Mr. Fox, by the apical median clypeal tooth.

Prof. Peckham informs me this species preys upon a Lygaeid belonging to the genus Pamera.

\section{THE LARVA OF CYDOSIA.}

It will be remembered by lepidopterists that the position of the genus Cydosia Westw., has been in dispute. In Smith's list of I89I, it appears in a subfamily Cydosiinae of Arctiidae. I have just learned from my friend Mrs. E. M. Swainson that she has discovered the larva in Jamaica, and she sends me some notes on the subject, along with a specimen of the moth. The particular spe- cies sent - the only one known to occur in Jamaica-is C. submutata (Walk.) Ckll., Journ. Inst. Jamaica, I893, p. $259(=C$. jamaicensis Ckll., Journ. Inst. Jamaica, 1892 , p. $135,=$ C. nobilitella (not Cram.) Butler ex err., P. Z. S., I878, p. 495). I give the account of the larva in Mrs. Swainson's own words:- "A pretty half looper larva, one inch and a half long, soft velvety black with orange marks all down back and at sides, between these are tiny pale yellow marks, on 

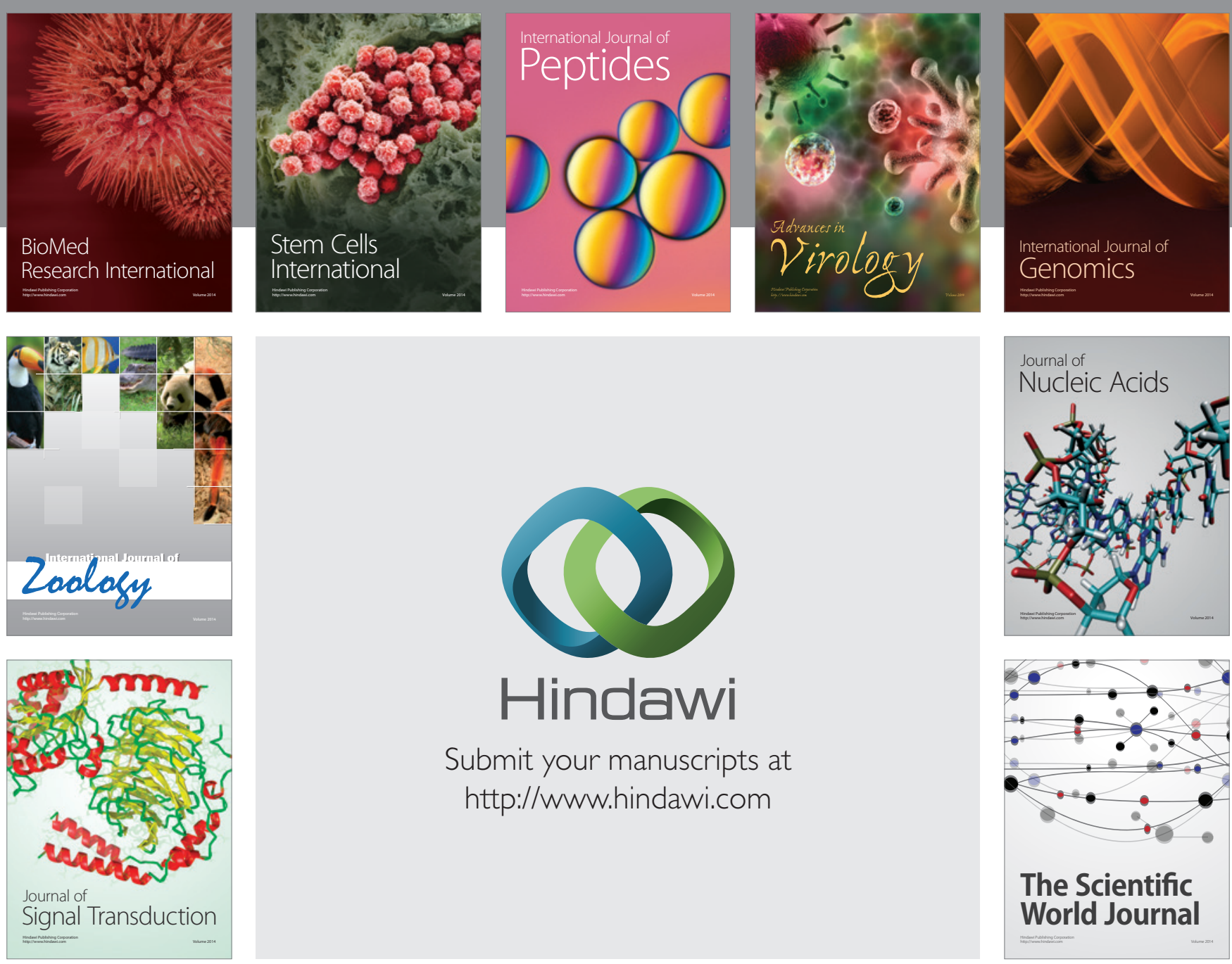

Submit your manuscripts at

http://www.hindawi.com
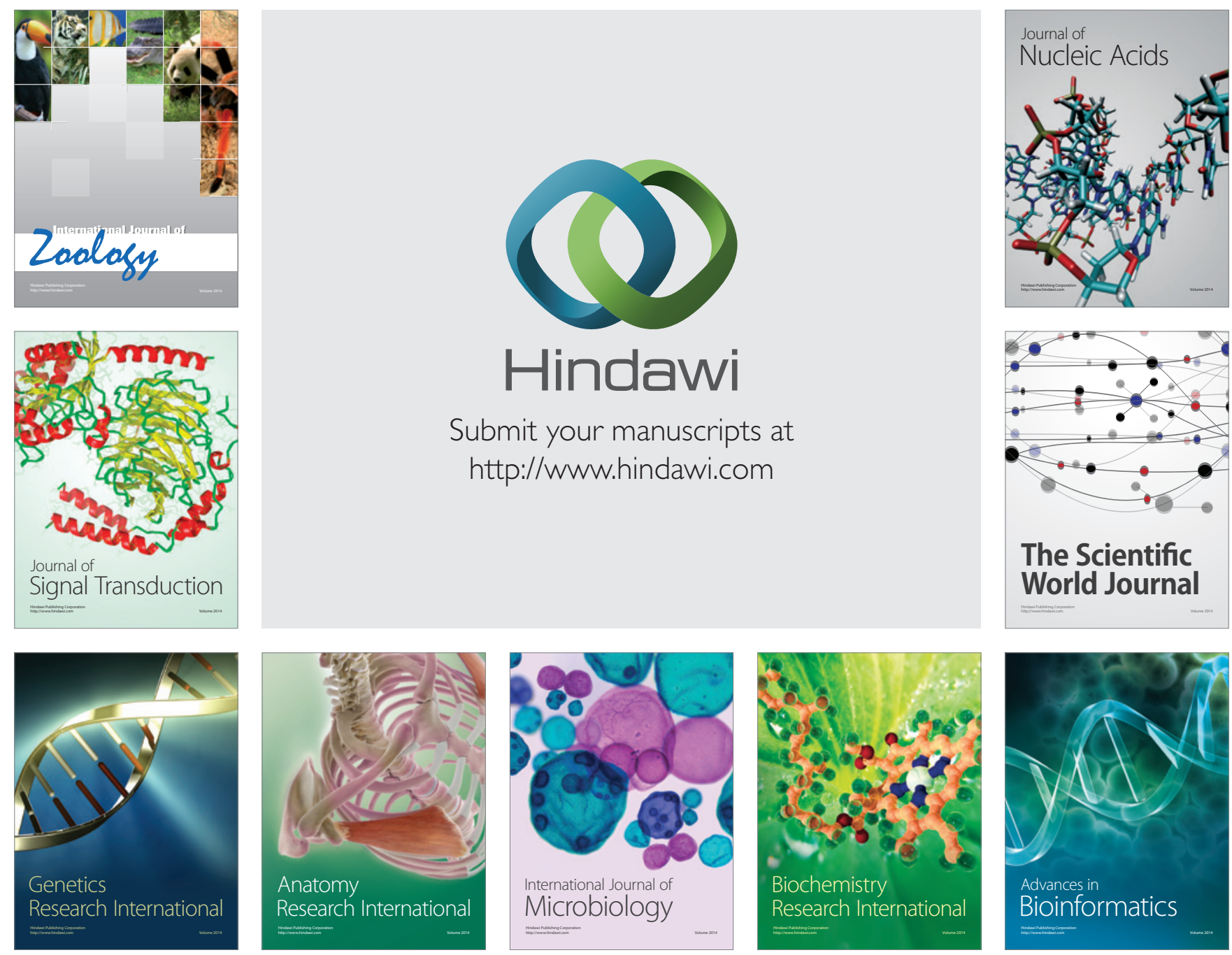

The Scientific World Journal
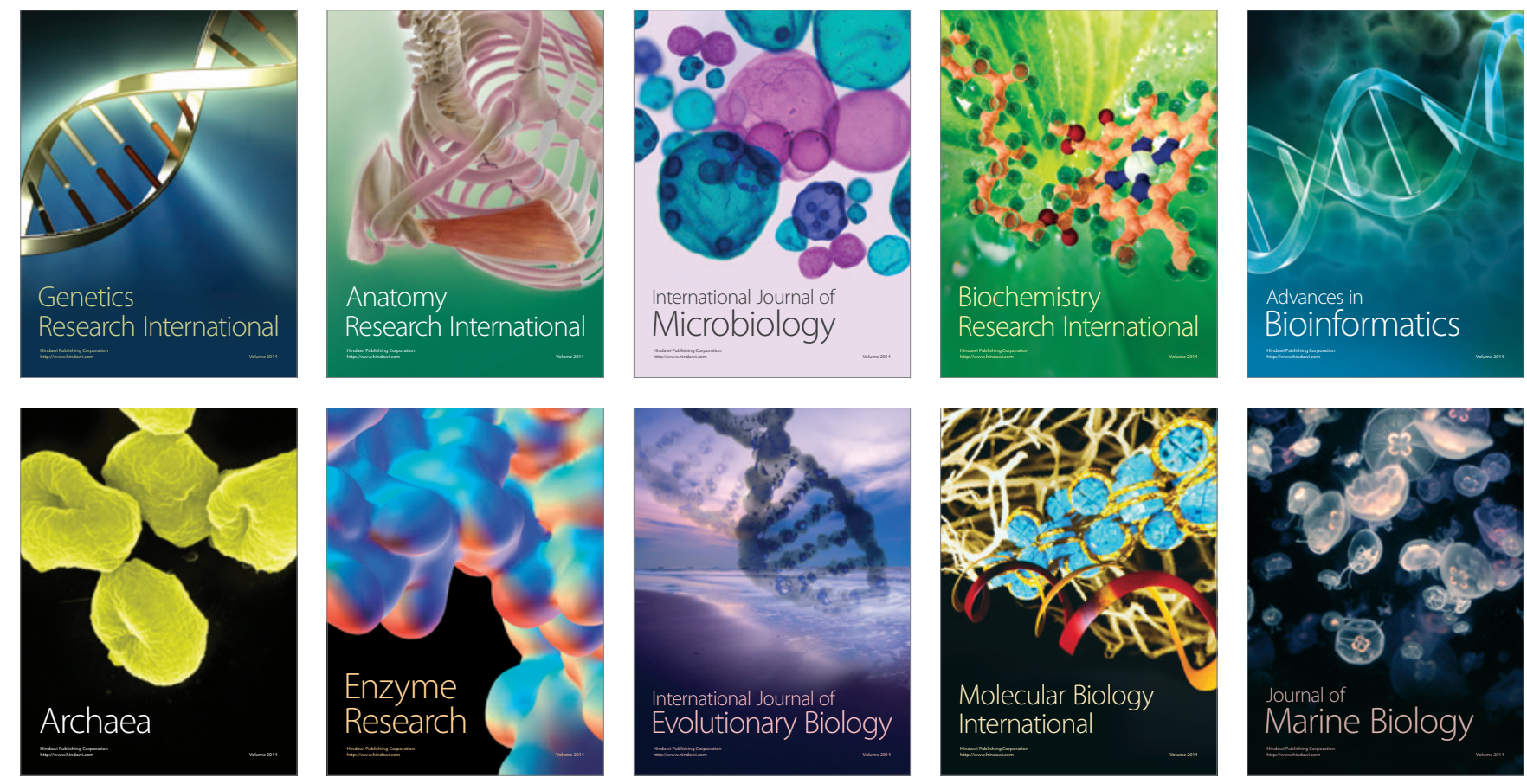